\title{
SMALL TOWNS AS CENTERS OF RURAL MICRO-REGIONS
}

\author{
Antonín Vaishar ${ }^{1}$ - Jana Zapletalová ${ }^{2}$
}

Received 12 September 2008; Accepted 16 December 2008

\begin{abstract}
Small towns ensure services on the basic urban level, jobs, social contacts, occasions to travel outside the micro-region, services of the state administration and sometimes also an identity of the micro-region. Mass commuting from villages to small towns is usual for Czechia for a long time. Small towns in peripheral regions are of our interest. Character of these towns is given by the remoteness and bad accessibility from regional centers, by the lack of investments, problems of human capital etc. Nevertheless, the peripheral small towns remain the definite centers of their hinterlands because of the lack of competition in majority of cases. The second demographic transition leads to ageing of rural population. Sub-urbanization and counter-urbanization impacts on the population shift from big and medium cities to the countryside. In the process of globalization, the countryside including small towns plays a role of bearer of the traditional way of life. Transferring the jobs from productive to non-productive branches endangers the countryside by losing jobs in industry. Increasing value of leisure, environment, space, security etc. offers new chances for small towns.
\end{abstract}

Key words: small towns, periphery, Czechia

Souhrn: Malá města zajišt'uji služby na základní městské úrovni, pracovní přiležitosti, sociální kontakty, př́ležitosti cestovat mimo mikroregion, služby státní správy a někdy identitu mikroregionu. Masová vyjížd'ka s venkova do malých měst je v Česku typická po dlouhé období. Předmětem našeho zájmu jsou malá města v periferních regionech. Charakter těchto měst je dán vzdáleností a špatnou dostupností regionálních center, nedostatkem investic, problémy humánního kapitálu atd. Nicméně malá města $v$ periferních regionech zůstávají nezpochybnitelnými středisky svého zázemí kvůli nedostatku konkurence. Suburbanizace a kontraurbanizace zpưsobily přesun obyvatel $z$ velkých a středních měst na venkov. V procesu globalizace hraje venkov včetně malých měst úlohu nositele tradičního způsobu života. Přesun pracovních príležitostí z výrobních odvětví do služeb ohrožuje venkov ztrátou míst v průmyslu. Zvyšující se hodnota volného času, životního prostředí, prostoru, bezpečnosti otevírá pro malá města nové příležitosti.

\footnotetext{
${ }^{1}$ RNDr. Antonín Vaishar, CSc. , Department of Applied and Landscape Ecology, Mendel University of Agriculture and Forestry Brno, Zemědělská 1, 61300 Brno, Czechia, e-mail: antonin.vaishar@uake.cz

${ }^{2}$ RNDr. Jana Zapletalová, CSc. , Department of Environmental Geography, Institute of Geonics, Czech Academy of Science Ostrava, v.v.i., Drobného 28, 60200 Brno, Czechia, e-mail: zapletalova@geonika.cz
} 


\section{Introduction}

Geographers usually perceive the reality regionally and in some hierarchic order. Almost none rural settlement (village) exists separately with its own detached local market of jobs and services. In central European conditions, the rural space is formed by micro-regions which usually consist of a micro-regional centre (a small town as a rule), and surrounding villages. Only these micro-regional scales enable creation of functioning market on the basic level.

Small towns ensure services of the basic urban level, jobs, social contacts, occasions to travel outside the micro-region, services of state administration and sometimes also the identity of the micro-region. Mass commuting from villages to small towns has been common in Czechia for a long time. Of course, the form and intensity of contacts between the small town and its villages is regionally differentiated.

The aim of the following paper is to analyse the role and position of Moravian small towns as centres of rural hinterlands in different types of regions. The prediction of the main trends is based on the analysis.

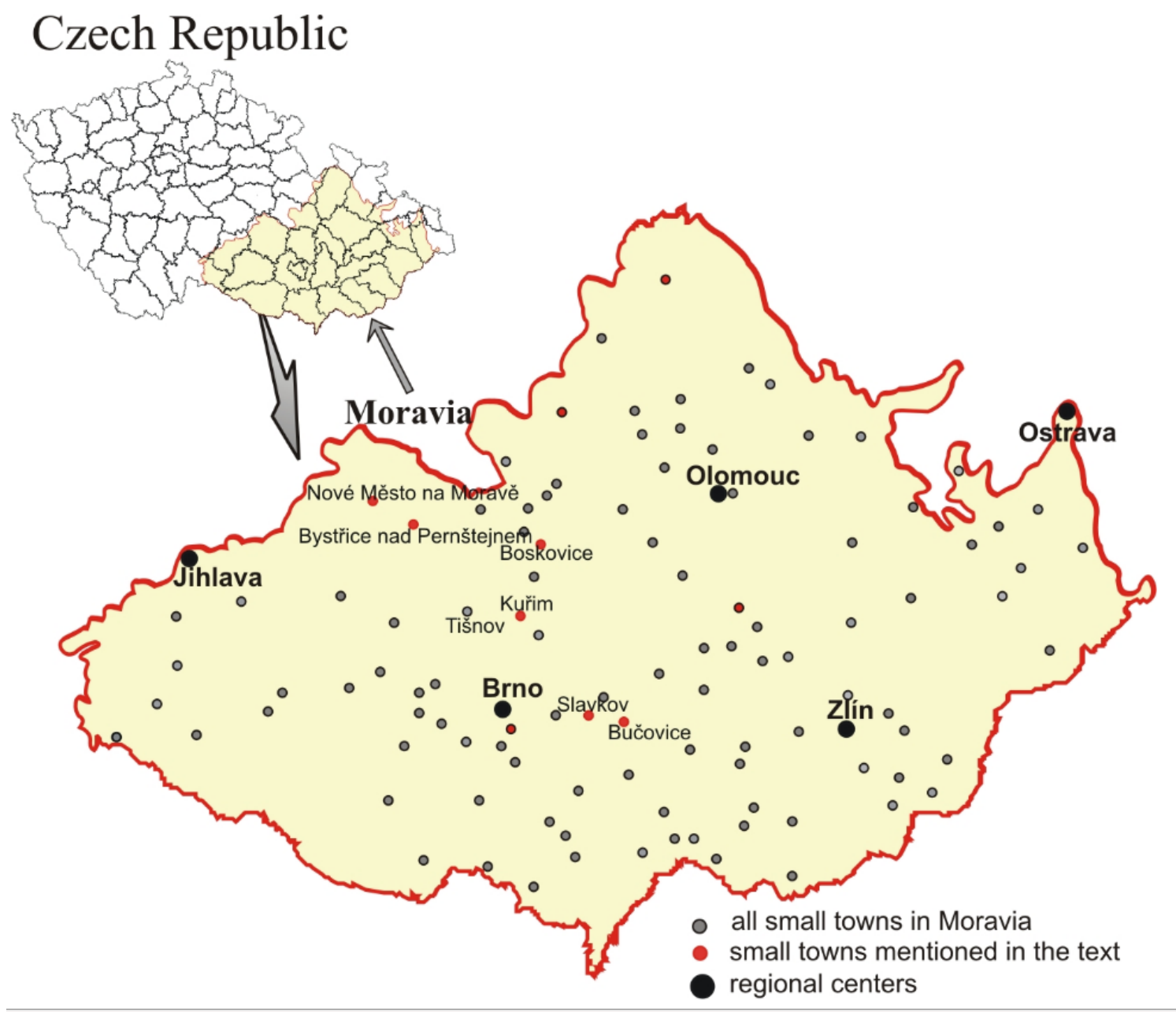

Fig 1. Small Moravian towns

Moravia is a historical land occupying the eastern part of the Czech Republic. It consists of urban and suburban regions of two larger cities of Brno and Ostrava, well accessible fertile lowlands in valleys of Morava, Svratka and Dyje rivers and peripheral mountain regions including borderland and so called inner periphery.

The small town sector was intensely investigated in the period of 1997 to 2005 within different grant projects. At the present time, investigations continue within the research program of Mendel University of Agriculture and Forestry in Brno and the research program of the Institute of Geonics, Czech Academy of Sciences. 


\section{Role of Small Towns in the Settlement System}

The investigation of small towns was omitted for a long time. Urban geographers were directed for cities as bearers of social progress and also as concentrations of environmental and social problems, whereas rural geographers investigated agriculture which does not very much concern small towns in the Czech conditions. At the present time, when agriculture is being repleced with multifunctional countryside in the perception of geographers, they have to pay logically more attention to small towns.

The books and papers dedicated to the small towns sector are appearing more and more frequently. The small towns still play an important role in European peripheral regions with absence of big and medium towns, e.g. the Alps manifest an inner periphery from the west European view. It is comprehensible that the small town research concentrates just into this space (Perlik-Bätzing 1999, Pumain 1999, Borsdorf-Paal 2000, Zsilincsar 2003). The problems of small towns are topical also in the southern part of France, interior Spain and also in other countries (e.g. Laborie 1997, Rodríguez Gonzáles 1997, Stewig 1987). The first scientific symposium organized by ECOVAST (European Council of Village and Small Town) took place in Murau, Styria in 1998 (Munduch-Spiegler 1998, Žigrai 2000), the following one in Weidhofen an der Ybbs (2002) and in Retz (2005). The general problems of the small towns in relation to the countryside were discussed by Courtney et al. (2007) or Edwards, Goodwin and Woods (2003). Some isolated monographs or papers about individual small towns (Roth 1961, Hajasová 2003), works about a small town within a larger region (Baran 1964, Meyer 2001) or an accentuation of some selected aspects of small towns (Slater 1977, Dövényi 1988, Taylor 2000, Łoboda 2002) could be named. There are also some relatively complex studies dated back to socialist period, e.g. Dziewoński (1957), Kiełczewska-Zaleska (1964) or Konstantinov (1966).

The post-socialist countries manifest themselves a European periphery as the whole. It is true also for Czechia with exception of Prague. But even here small towns do not raise any big attention of experts. Also the Czech geographic literature concerns the small towns sector mainly within evaluation of the whole settlement system, within analyses of large regions or within isolated cases studies. Various theses ordered in individual geographical departments at Czech universities aimed at elaboration of a selected town have such a pattern. Hardly any generalization originates from such works.

The consequences of transformation from the centrally-planned to the market-oriented economy are the main focuses of the small town research in post-socialist countries. German colleagues concentrated on the transformation of the settlement structure after the re-unification of Germany (Niedermeyer 2000 or Steinführer and Kabisch 2004). Slavík (2002) pays a complex attention to small towns in Slovakia, Sokołowski (1999) in Poland. Zuzańska-Żyśko (2003, 2004) studies small towns in Silesia and Kwiatek-Sołtys (2004) in the Malopolska region. In general, the Polish geography deals with small towns as centres of rural hinterland (e.g. Heffner, Marszał 2005, Rydz 2006) in the last time. Monographs or papers about small towns occur also in other post-socialist countries (Rebernik 2005). To elaborate a strategy for individual small towns is usually their aim.

In the Czech geography small towns are on the periphery of the interest. Small towns are studied - if ever - as a part of larger regions (e.g. Hřebík et. al. 2006). In the last time, geography of peripheral areas and/or the borderland has been developed at Charles University in Prague and some other universities. Small towns are mentioned as a part of such peripheries (e.g., Jančák 2001, Novotná 2005). But there is no publication focused on small towns as a feature in the Czech geography possibly with an exception of some sociological studies (Jeřábek 2000).

Our team with foreign collaborators brought some tribute to the general knowledge. First issues were directed on problems of individual small towns: Vaishar - Zapletalová (1998), Vaishar et al. (2001), Vaishar - Kallabová - Zapletalová (2002), Mikulík - Vaishar (2003). Step by step, sectoral problems were taken into account (Vaishar - Kallabová (2001), Vaishar - Kallabová Trávníček (2002), Vaishar - Kirchner - Lacina (2004). Some attempts on general evaluation were made (Vaishar 2003, 2004, 2006, Vaishar - Greer Wootten 2006). Also an international 
comparison was made (Cigale et al. 2006, Lampič - Špes 2007). Perception of small towns as centres of rural hinterland came into consideration necessarily (Vaishar 2005).

\section{Small Town Investigation Approach}

Small towns (statistically defined as communes with $2-20$ thousand inhabitants) take up a relatively important position in the Czech settlement system (table 1).

\begin{tabular}{|c|l|c|c||}
\hline Population Size & Type & Inhabitants & $\%$ \\
\hline $5-1999$ & Rural communes & 2672825 & 26,0 \\
\hline $2000-19999$ & Small Towns & 2983560 & 29,0 \\
\hline $20000-99999$ & Medium-scale towns & 2489927 & 24,1 \\
\hline 100000 and more & Big cities & 2146621 & 20,9 \\
\hline
\end{tabular}

Tab 1. Population numbers according to the settlement types (population census 2001)

It is obvious from the table that $55 \%$ of the Czech population lives in rural communes and small towns. From this viewpoint, Czechia seems to be a rural country. The second important conclusion is, that of the mentioned four categories, the biggest portion can be found in small towns. Explaining the fact, we have to go to the beginning of the Czech industrialization. Because of lack of urban capital, Czech industrialization was based mostly on the noblemen investments which were dispersed in the country (Blažek 1969). From this reason about a quarter of Czech communes have had an industrial plant and Czech small towns are mostly industrialized. The socialist period conserved the situation by means of the politics of decentralization. The present era of suburbanization and counter-urbanization keeps the role of small towns in the settlement system. It shows that it is much better to direct suburbanization to small towns in surroundings of big cities than to accept urban sprawl (Vaishar - Zapletalová 2008).

The research was focused on municipalities with the town status, whose populations are below 15 thousand inhabitants. There are a total of 109 municipalities like these in Moravia. Their total number of inhabitants in 2001 was about 600 thousand. In the intracensal period of 1991-2001, the number of inhabitants decreased by $2.54 \%$ in these towns, while the country's population decreased by $7.00 \%$, this indicating that the proportion of inhabitants living in the small Moravian towns in the total Czech population slightly increased. The fact apparently fully justifies the attention paid to the small towns.

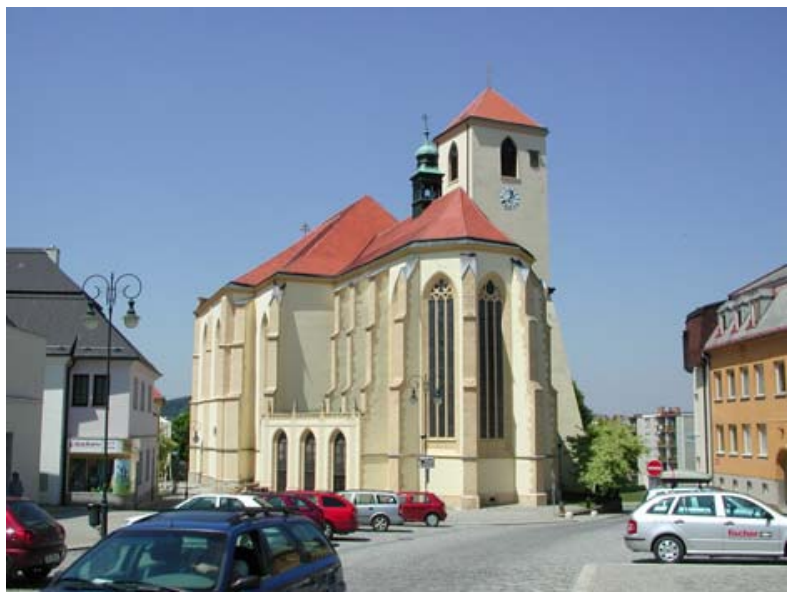

Fig 2. Boskovice - the core of a typical small town in inner periphery

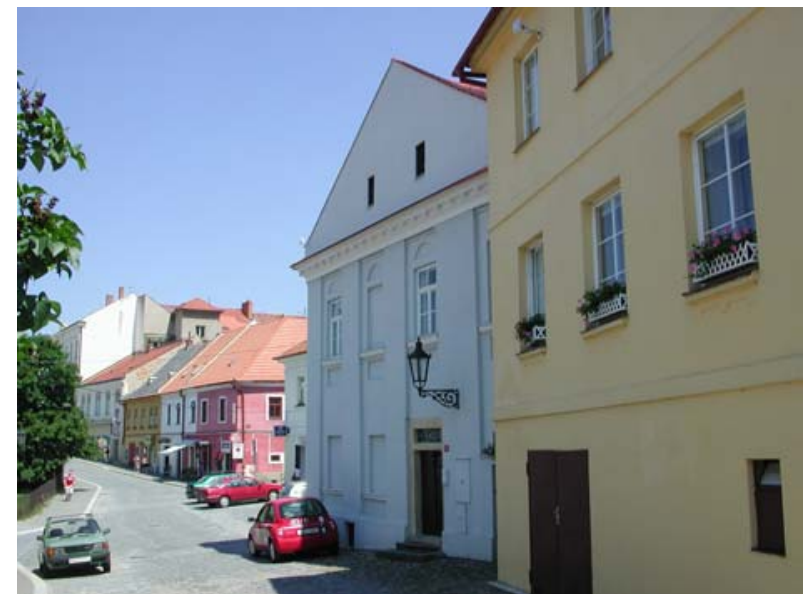

Fig 3. Former Jewish town in Boskovice was successfully restored

There were 35 case studies made coming from the methodology of regional geography (a small town with its territory and functional structure as a micro-region). It enabled to understand more interrelations among individual elements and features. The whole set of towns was compared 
by means of statistical data of different character. As a consequence of this approach, we were able to analyse the whole set of small towns of historical Moravia and to suggest some typology.

Zuzańska-Żyśko (2007) mentions two categories: small towns as centres of rural hinterland or specialized small towns (in industry or tourism). We defined three basic types (divided further to sub-types) of small Moravian towns (not taking into account small towns which have the administrative status of a town but in fact the have almost no urban functions and monofunctionally industrial small towns without any central importance).

The small towns in the hinterlands of big cities form the first group. But these suburbanised small towns are losing their central function which is overlapped by central functions of the big city. Certain danger of a lapse of the identity of suburbanised small towns by big cities was predicted. This category is not the subject of our paper.

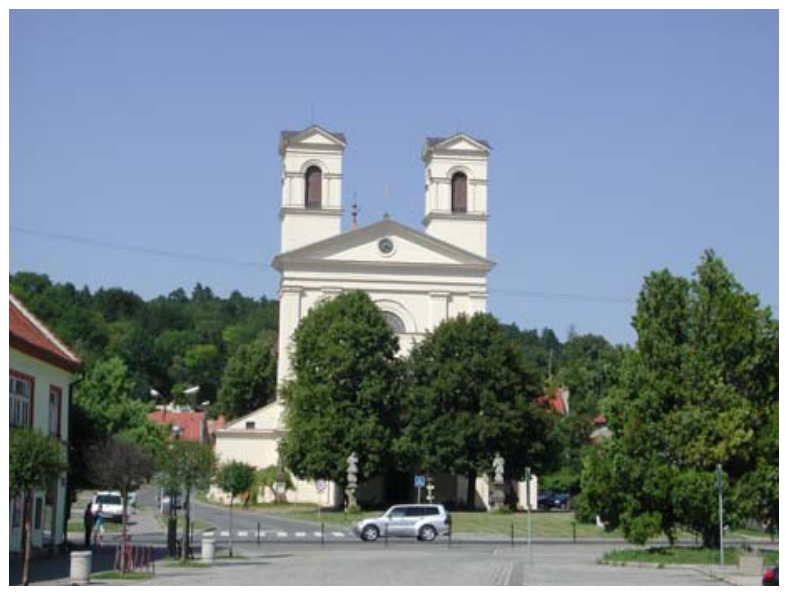

Fig 4. Bučovice: St. Lawrence church is divided from the rest of the main square by the main road from Brno to Slovakia

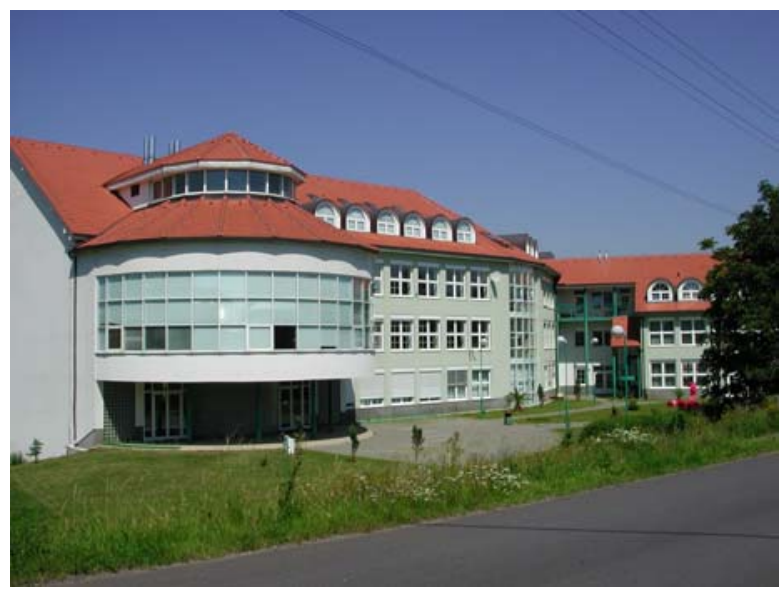

Fig 5. Bystřice nad Pernštejnem: new building of the grammar school

The small towns in well-accessible landscape of fertile Moravian lowlands form the second category. Also in this case, the central importance of small towns is not very expressive. The settlement structure in Moravian lowlands consists of a relatively regular network of small towns and big villages. Each of these settlements has its own local market not dependant on jobs and services of the neighbouring ones. Additionally, due to advantageous transport conditions for both individual and public transport, big and medium towns are relatively easily accessible from villages in theoretical hinterlands of small towns. It means that the rural people in lowlands can satisfy their needs either in their own big villages or in big or medium cities which are usually better equipped than the closest small town. The suggested strategy for the future of small towns in lowlands is a specialization (in industry, education, health-care, tourism) and division of functions.

The third category is created by small towns in peripheral positions. Such positions can be found in the borderland (which is formed by mountain ranges in majority of cases) or in the inner periphery (the natural border between historical Moravia and Bohemia and some hilly regions in the interior of the land). Their marginality is preconditioned by difficult accessibility due to hilly relief, by the distance from the main centres and sometimes also by the border which limits their development.

The hinterland of peripheral small towns consists often of a big number of small villages not very far from one another. These small villages have hardly any own local market. They are entirely dependent on their small towns which ensure job opportunities, services, social contacts, transfer points for travelling to the more distanced towns etc. Although the small towns in peripheral regions are poor with lack of investments, they are usually unquestionable centres of their hinterland. It is inevitable that the peripheral small towns are the right subject of our discussion. 


\section{Small Towns as Centres of Rural Micro-Regions}

Peripheral small towns form the biggest group among all categories. At the same time, the group is relatively diversified according to the size, functions and historical development in the last century. It is necessary to state that the population of majority of small towns in the borderland (except the Slovak border) has been changed after the WW II. Specific demographic and social milieu has been observed in the affected towns up to the present time.

The problems of peripheral small towns result from the table 2. The lack of investments is the first big disadvantage. The small towns and their rural hinterland depend on industrial jobs in a relatively large extent. A lot of mayors attempt to create industrial parks offering some privileges for investors. But the enthusiasm of investors is not very high taking into account problems of transport of raw materials and products. This situation is sometimes complicated also by certain factors e.g. an apprehension of managers (or their family relatives) to resettle into periphery.

\begin{tabular}{||l|l||}
\hline \hline $\begin{array}{l}\text { Strengths } \\
\text { - Definitive central function as } \\
\text { a consequence of a lack of competition }\end{array}$ & $\begin{array}{l}\text { Weaknesses: } \\
\text { - Lack of investments including foreign }\end{array}$ \\
\hline$\quad$ Bearers of regional identity & $\begin{array}{l}\text { Low purchasing power of local population } \\
\text { in the town and its hinterland }\end{array}$ \\
\hline $\begin{array}{l}\text { Occasions: } \\
\text { - Gain of financial sources from the } \\
\text { structural funds or within the regional } \\
\text { politics }\end{array}$ & $\begin{array}{l}\text { Threats: } \\
\text { - Decrease of economic power under the } \\
\text { Improvement of transport connection or limit under the market conditions } \\
\text { a change of character of the border }\end{array}$ \\
\hline
\end{tabular}

Tab 2. SWOT analysis of peripheral small towns

The second problem is related to the fact that the periphery is usually poor. The structure of jobs does not allow to increase the purchasing power of local inhabitants. Business people cannot expect high benefits. Consumers consider each expenditure (this explains why highlanders, e.g. Scottish are reputedly miserly). A fall of the economic power of such small town with its hinterland under the critical limit is the main threat which could lead to some depopulation. But in fact, it has happened in Czechia only in relation to the consequences of the displacenets of German population after the W W II.

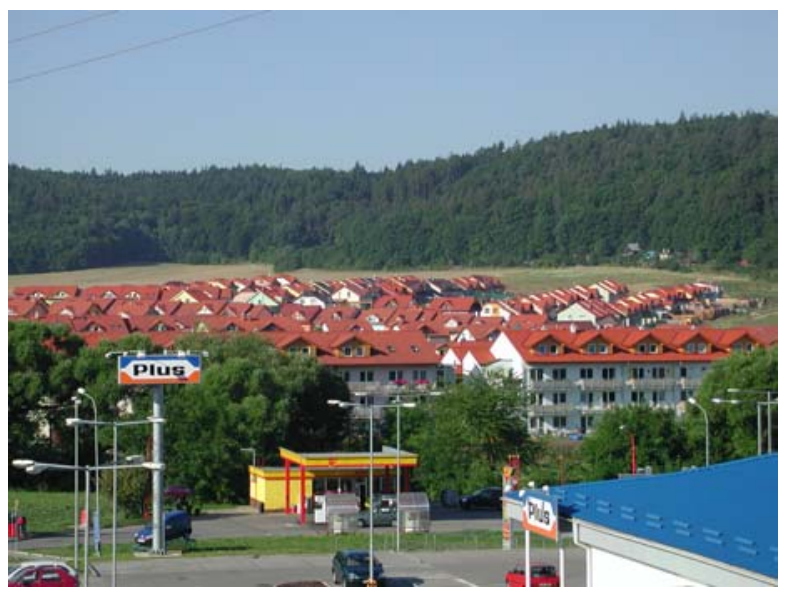

Fig 6. Kuřim: an example of an suburbanised small town

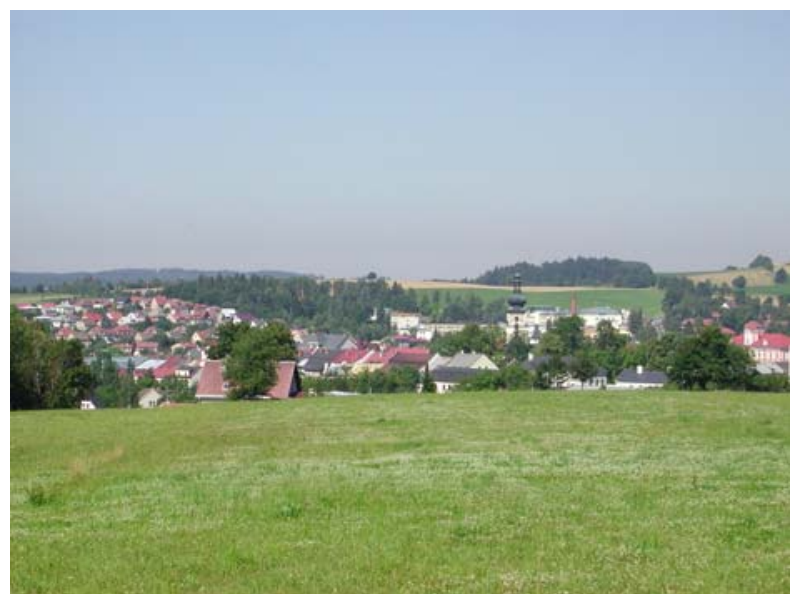

Fig 7. Nové Město na Moravě: general view 
On the other hand, the lack of competitive towns and cities is a big advantage of peripheral small towns. Bigger towns are far-away, surrounding villages are too small to have some important activities. Entrepreneurial benefits directed to the local markets are low but relatively sure. To change the main disadvantage to an advantage using the lack of competition is a point of a success.

There is a splendid example in pre-war Moravia. The town of Zlín situated in the narrow valley of the Dřevnice river in the peripheral position of eastern part of the land had about 3 thousand inhabitants when Tomáš Bat'a started his business activities. Besides the local tradition in workmanlike production of shoes he used a cheap labour force, cheap prices of land and better position in negotiation with local authorities. He built the settlements themselves as well as the technical and social infrastructure. Consequently he was elected a mayor of the town and a head of the big shoemaking empire with factories all over the world world. Anything like that would not be possible somewhere in a metropolis. The town of Zlín grew to the position of the centre of eastern Moravia. It has more than 100 thousand inhabitants together with the town of Otrokovice (developed also by Bat'a).

Of course, not all towns can be like Zlín and not all entrepreneurs like Bata. But the example shows that there is certain potential in many peripheral small towns. To have a vision based on some traditional or new, natural or human factor is the presupposition. To use the advantages together with a very limited competition on the local market is the framework. At the present time, the way could be made mote smoothly with the aid of EU structural funds and under the condition of elimination of the border barriers within the Schengen area.

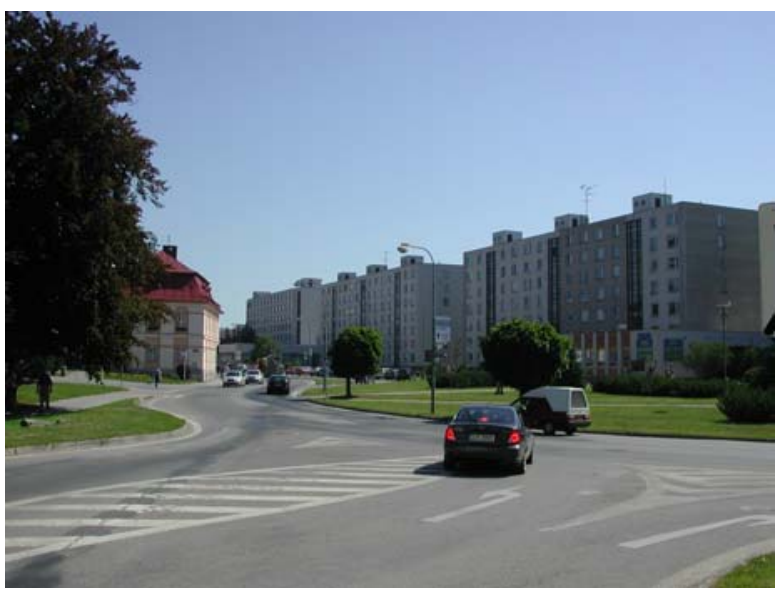

Fig 8. Nové Město na Moravě: prefabricated houses penetrated to the vicinity of the historical core

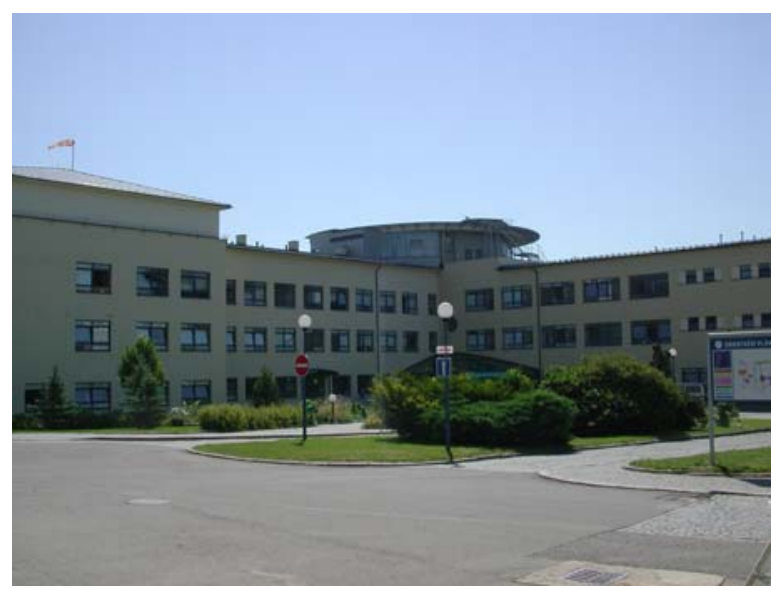

Fig 9. Nové Město na Moravě - hospital, pavilion of surgery; an example of specialization

\section{Future of Moravian Rural Space with Small Towns}

The following hypothetical processes should be taken into account speaking about the future of the Moravian rural space and the role of small towns in its development:

The second demographic transition. Its consequences (concerning the autochthonic population) consist in a decreasing share of young people, increasing share of seniors (together with elongating life expectancy), decreasing size and increasing number of households. The process proceeds no matter of urban or rural population, size of settlements, religiosity etc. More flats for less people could be the manifestation of this development in the physical structure of small towns. The immigration from other countries (often from culturally distanced ones) is the other side of the fact, which must be taken into account. It is possible to predict that immigrants from the South and East will be directed to bigger cities at first but they can emerge also in small towns and villages. Other type of expected immigration is connected with amenity migration of people from such countries as Germany, the Netherlands etc. These motions of population can be headed to the rural space. It is presupposed that the subjects of the amenity migration will be interested in keeping certain social standards (health care, services etc.) ensured in small towns. 
Suburbanization and counter-urbanization. Small towns can be the aim of population moving from big and medium cities and sources of out-migration to villages at the same time. In the vicinity of big cities, the first movement prevails. It is possible to point that suburbanization directed from big to small towns lacks some disadvantages of the same process directed to villages, newly concentrated settlements or even urban sprawl. Small towns dispose of basic urban services, frequent connections of public transport, some historical, cultural and infrastructural base for social life. Their problem could consist in weaker identity which threatens with fusion with the identity of the big neighbour. We perceive the local identity as a very important motivation factor for local as well as micro-regional development.

Globalization. The process proceeds from metropolises to big and medium cities. The countryside including the small towns remains at the margin of this process. This could be a disadvantage for the people looking for the latest achievements. On the other hand, small towns together with their rural hinterland are becoming the bearer of regional identity or sustainability of the traditional way of life. Of course, in the era of rapid globalization process, the time difference between big and small town concerning access of global features shortens. Nevertheless, small towns allow the people a possibility to consume global advantages in big cities and to compensate it with more traditional way of life in small towns.

Continuation of transfer the jobs from productive to non-productive sectors. The Czech small towns are in general relatively highly industrial as a consequence of their historical development. That is why the countryside is endangered much more by the decrease of jobs in industry than by decrease of employment in agriculture. It seems to be a big problem of small towns. Better situation is observed in small towns with tourist function (spas, mountain tourist resorts etc.) or small towns with some specialization in services (e.g. secondary schools, health care, social services).

Increasing value of leisure, environment, space, security etc. for inhabitants. The current market-oriented society is aimed at financial or economic benefits. But this orientation could clash with some barriers in the future. A big ownership could be unavailing or inefficient when it is absorbed by decreasing costs of environmental security, personal security combined with a lack of leisure time etc. The small towns with their more traditional way of life, higher security due to social control and better environmental characteristics could be sought after by people looking for new values. An attack of terrorist in a small town is much less probable than in a big city.

Decreasing importance of the state border as a barrier of development. Borderland is a special case of rural Czechia. With exception of the Ostrava region, north-west Bohemia and some individual exceptions in a form of medium towns, the Czech borderland is rural, peripheral and often also marginal. Unfortunately, the Czech borderland is mostly formed by natural limits (mountains, rivers). But there are some cases when the space is open into the neighbouring country. This fact puts a question if the cross-border co-operation can overcome the remoteness from the national viewpoint. Of course, it is also a question of a psychological barrier, knowledge of languages, economic differences etc. But all these factors will certainly decrease in the future.

\section{Investigating Small Towns within Rural Research}

We are convinced that especially peripheral small towns are worth of the next investigation particularly from the viewpoint of their role for the rural hinterland. Lichtenberger (1989) mentions that small towns manifest relatively stable element of the (Austrian) national settlement system. It seems to be true also for Czechia. Are there any presuppositions to keep this positive role of small towns? The answer depends on confirmation or confutation the hypotheses mentioned above and on a definition of their mutual relations.

It makes hardly any sense to study rural space and not taking into account central small towns and vice versa. The rural hinterlands play a role of the micro-regional market of small towns. It is hardly possible to explain the role of a small town in the settlement system not having in mind its hinterland. It could be examined if it is valid that the stronger centre the stronger its rural hinterland, too. 
It implies that a micro-regional investigation based on methods of regional geography comes into consideration. The relations between small towns and rural settlements in their hinterlands should be of a great attention. The following aspects are of big importance: position with regard to regional centres, natural conditions with regard to the micro-regional development (agriculture, raw materials, tourism, hazards etc.), human capital and its development and existing economic and non-economic activities among others. Also an image of the micro-region seems to be an important research question.

Additionally, the Czech administrative structure is typical with a very high number of communes, of which a big majority belongs to small and very small settlements. In the whole Czechia, $59.1 \%$ of communes have less than 500 inhabitants and $26,5 \%$ have even less than 200 inhabitants. Such small communes have hardly any efficient possibility to execute the state administrative function neither to ensure the development due to limited budgets and a limited human capital. The administrative situation is solved by delegation of certain functions (e.g. registry office, trades licensing office, issuing of personal and travel documents, evidence of vehicles, payout of social benefits etc.) to selected communes with bigger human and financial potential. The small towns are the seats of offices with this delegated competence in many cases. The weakness of self-governance in small communes is solved by creation of voluntary associations of communes as legal subjects with small towns as their centres as a rule. Although the mentioned processes does not generate relation superiority and subordination between small towns and surrounding communes, some way of micro-regional integration originates also in the administrative field.

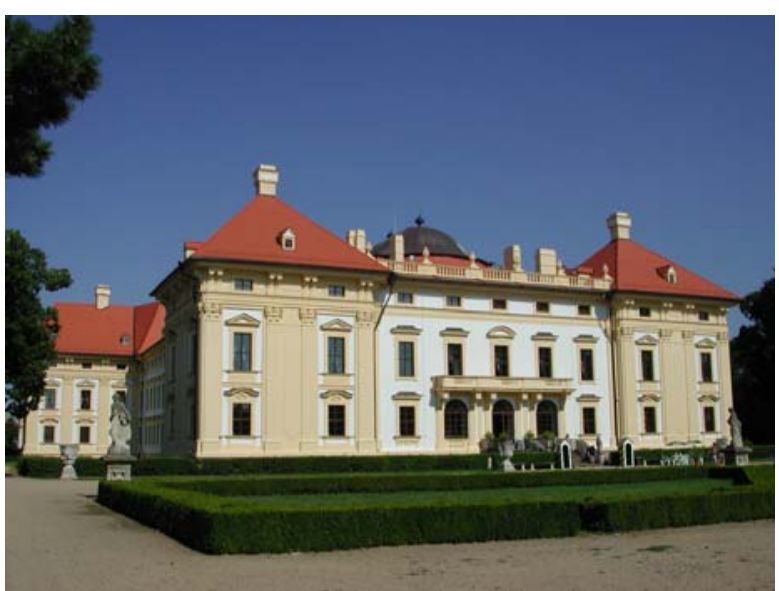

Fig 10. Slavkov u Brna (Austerlitz) an example of historical heritage in small towns

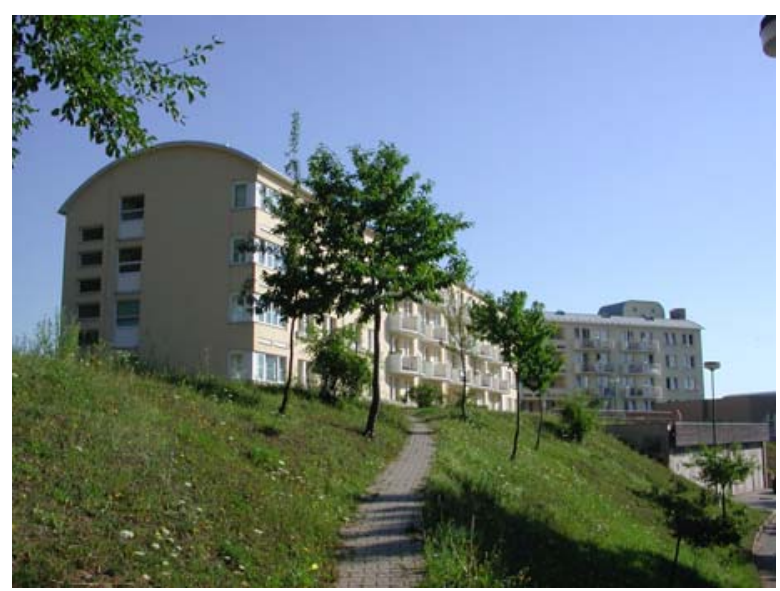

Fig 11. Tišnov: houses for seniors are often among the most impressive buildings in small towns

The international aspect of the research is also a matter of interest. In our opinion, the transformation from the centrally planned to the marked oriented economy finalizes. The post socialist countries inhere at the door of more general trend - the globalization. Of course, the cities reached the globalization process earlier then the countryside. But also the eastern European rural space is becoming a subject of globalization step by step. It opens the allEuropean research horizon for the small-town sector, too.

\section{References}

[1] BARAN, V. (1964): Moldava nad Bodvou. In K. Ivanička (ed.): The Geography of the Region of the East-Slovakian Iron-Works (pp. 321-337). Bratislava: SPN.

[2] BLAŽEK, M. (1969): Některé rysy urbanizace v ČSSR. In: Problémy rozvoje Ostravské aglomerace. (pp. 10-21). Ostrava: Ústav pro výzkum rozvoje měst.

[3] BORSDORF, A., PAAL, M. (2000): Die „Alpine Stadt“ zwischen lokaler Verankerung und globaler Vernetzung. Wien: Verlag der Österreichischen Akademie der Wissenschaften Wien. 
[4] CIGALE, D., LAMPIČ, B., OGRIN, M., PLUT, D., REBERNIK, D., ŠPES, M., VINTAR MALLY, K., CETKOVSKÝ, S., KALLABOVÁ, E., VAISHAR, A., ZAPLETALOVÁ, J. (2006): Sustainable Development of Small Towns: A Slovenian-Czech Comparative Methodological Approach. Moravian Geographical Reports 14(1), 17-28.

[5] COURTNEY, P., MAYFIELD, L., TRANTER, R., JONES, P., ERRINGTON, A. (2007): Small towns as 'sub-poles' in English rural development: Investigating rural-urban linkages using sub-regional social accounting matrice. Geoforum 38(6), 1219-1232. DOI: 10.1016/j.geoforum.2007.03.006.

[6] DÖVÉNYI, Z. (1988): Some Problems of Small Towns in the Great Hungarian Plain. In: Lichtenberger, E., Pécsi, M. (eds.): Contemporary Essays in Austrian and Hungarian Geography (pp. 251 - 262). Budapest: Akadémiai Kiadó.

[7] DZIEWOŃSKI, K. et al. (1957): Studia geograficzne nad aktywizacją małych miast. Warszawa: PWN.

[8] EDWARDS, B., GOODWIN, M., WOODS, M. (2003): Citizenship, community and participation in small towns: a case study of regeneration partnerships. In: Imrie, R., Raco, M. (eds.): Urban renaissance? New labour, community, and urban policy (pp. 181-204). Bristol: Policy Press.

[9] HAJASOVÁ, K. (2003): Mesto Nová Dubnica v období transformácie. In: Novák, S. [ed.]: Geografické aspekty středoevropského prostoru. (pp. 191-195). Brno: Masarykova univerzita.

[10] HEFFNER, K., MARSZAŁ, T. (eds.) (2005): Problemy rozwoju małych miast w wymiarze lokalnym i regionalnym. Warszawa: Komitet przestrzennego zagospodarowania kraju PAN.

[11] HŘEBÍK, Š., NOVÁK J., TŘEBICKÝ, V. (2006): Kam směřuje rozvoj malých měst a obcí Středočeského kraje? Karlštejn: Společnost pro rozvoj Českého krasu.

[12] JANČÁK, V. (2001): Př́spěvek ke geografickému výzkumu periferních oblastí na mikroregionální úrovni. Geografie 106(1), 26-35.

[13] JEŘÁBEK, M., MÜLLER, B., KUČERA, K., PŘIKRYL, J. (2000): Vnímání socioekonomického vývoje $v$ česko-saském pohraničí - př́ípadová studie na lokální úrovni měst Kraslice / Klingenthal. Geografie 105(1), 19-33.

[14] KIEŁCZEWSKA-ZALESKA, M. (1964): Changes in the functions and structure of small towns in Poland. Geographica Polonica 33, 79 - 92.

[15] KONSTANTINOV, O. A. (1966): Dinamika v razmeščenii malych gorodov SSSR. Voprosy geografii naselenija (pp. 4-24). Leningrad: Pedagog. Institut.

[16] KWIATEK-SOŁTYS, A. (2004): Małe miasta województwa małopolskiego w okresie transformacji systemowej. Kraków: Wydawnictwo Naukowe Akademii Pedagogicznej Kraków.

[17] LABORIE, J.-P. (1997): Les petites villes et la métropolisation. In: Laborie, J.-P., Renard, J. (eds.): Bourgs et petites villes (pp. 21-48). Toulouse: Presses universitaires du Mirail.

[18] LAMPIČ, B, ŠPES, M. (eds.) (2007): Sustainable development of small towns. Ljubljana/Brno: Filozofska fakulteta Univerze v Ljubljani and Ústav geoniky AV ČR.

[19] LICHTENBERGER, E. (1989): Österreich: Raum und Gesellschaft. Wien: Verlag der Österreichischen Akademie der Wissenschaften.

[20] ŁOBODA, J. (2002): Small Towns in the Sudeten Region of Poland. In: Davies, W., Townshend, I. (eds.): Monitoring cities: international perspectives (pp. 157-174). Calgary/Berlin: IGU.

[21] MEYER, K. (2001): Entwicklung und Struktur der Städte in Castilla y León (Spanien). Passau: Fach Geographie der Universität Passau. 
[22] MIKULÍK, O. - VAISHAR, A. (2003): Frenštát pod Radhoštěm: The Town of Mining or the Town of Tourism? In: Vaishar, A. - Zapletalová, J. - Munzar, J. (eds.): Regional Geography and its Applications (pp. 118-127). Brno: Regiograph Brno.

[23] MUNDUCH, E.M., SPIEGLER, A. (1998): Kleinstädte. Motoren in ländlichen Raum. Tagungsband anlässlich des ersten mitteleuropäischen Kleinstadtsymposiums in Murau 1998. In: Landtechnische Schriftenreihe No. 214. Wien: Österreichisches Kuratorium für Landtechnik und Landentwicklung.

[24] NIEDERMAYER, M. (2000): Regulationsweisen der Kleinstadtentwicklung. Eine Analyse peripherer Kleinstädte im Grenzraum von Südthüringen und Nord-Unterfranken. In: Niedermayer, M.(ed.): Kleinstadtentwicklung. (pp. 47-375). Würzburg: Geographisches Institut der Universität.

[25] NOVOTNÁ, M., ed. (2005): Problémy periferních oblastí. Praha: Universita Karlova.

[26] PERLIK, M., BÄTZING, W. (1999): L'avenir des villes des Alpes en Europe. Bern: Verlag des Geographischen Institutes der Universität.

[27] PUMAIN, D. (1999): Quel rôle pour les villes petites et moyennes des régions périphériques? Revue de Geographie Alpine. 87(2), 167-184.

[28] REBERNIK, D. (2005): Small towns in Slovene urban system. In: Murayama, Y., Du, G. (eds.): Cities in global perspective - diversity and transition (pp. 172-180). Tokyo: College of Tourism of the Rikkyo university / International Geographical Union - Urban Commission.

[29] RODRÍGUEZ GONZÁLES, R. (1997): La urbanización del espacio rural en Galicia. Barcelona: Oikos-tau.

[30] ROTH, K. (1961): Die Stadt Lahr. Bad Godesberg: Bundesanstalt für Landeskunde und Raumforschung.

[31] RYDZ, E. (ed.): Rola małych miast w rozwoju obszarów wiejskich. Warszawa: Polskie towarzystwo geograficzne i Institut geografii i przestrzennego zagospodarowania.

[32] SLATER, T.R. (1977): Landscape parks and the form of small towns in Great Britain. Transactions of British Geographers, 2(3), 314-331.

[33] SLAVÍK, V. (2002): Small Towns of the Slovak Republic within the transformation stage. In: Matlovič, R., Žigrai, F. (eds.): Wandel der regionalen Strukturen in der Slowakei und im österreichischslowakischen Grenzgebiet (pp. 146-154). Prešov: Prešovská univerzita.

[34] SOKOŁOWSKI, D. (1999): Funkcje centralne w zbiorze małych miast i większych osiedli wiejskich w Polsce. Przegląd geograficzny 71(3), 295-316.

[35] STEINFÜHRER, A., KABISCH, S. (2004): Binnen- und Außenimage von Johanngeorgenstadt aus soziologischer Perspektive. Leipzig: Umweltfroschungszentrum Leipzig Halle $\mathrm{GmbH}$.

[36] STEWIG, R. (1987): Untersuchungen über die Kleinstadt in Schleswig-Holstein. Kiel: Christian-Albrechts-Universität Kiel.

[37] TAYLOR, Z. (2000): Przekształcenia sieci handlu detalicznego i gastronomii w okresie transformaci społeczno-gospodarczej Polski. Wrocław: Continuo.

[38] VAISHAR, A. (2003): Small towns as a specific phenomenon of the settlement system. Case study Moravia. EUROPA XXI 10, 25-34.

[39] VAISHAR, A. (2004): Small towns: an important part of the Moravian settlement system. In: Pak, M., Rebernik, D. (eds.): Cities in transition (pp. 309-318). Ljubljana: Univerza v Ljubljani.

[40] VAISHAR, A. (2005): Small Towns as Centres of Rural Microregions. In: Komornicki, T., Czapiewski, T. (eds.): Central and Eastern Europe: Changing Spatial Patterns of Human Activity (pp. 53-62). Warszawa: Institute of Geography and Spatial Organization PAN. 
[41] VAISHAR, A. (2006): Geography of Small Towns. In: Lois Gonzáles, R.C. (ed.): Urban changes in different scales: Systems and structures (pp. 297-308). Santiago de Compostela: Universidade de Santiago de Compostela.

[42] VAISHAR, A. et al. (2001): Geography of Small Moravian Towns: Case Study Bučovice. Moravian Geographical Reports 9(1), 43-62. ISSN

[43] VAISHAR, A., GREER-WOOTTEN, B. (2006): Sustainable development in Moravia: An interpretation of the role of the small-town sector in transitional socioeconomic evolution. In: Bochniarz, Z., Cohen, G.B. (eds.): The environment and sustainable development in the new central Europe (pp. 217-231). New York - Oxford: Berghahn Books.

[44] VAISHAR, A., KALLABOVÁ. E. (2001): Vývoj služeb v malých moravských městech po roce 1990. Geografie 106(4), 251-269.

[45] VAISHAR, A., KALLABOVÁ, E., TRÁVNÍČEK, B. (2002): Der Strukturwandel der Kleinstädte in Mähren. Europa Regional 10(4), 166-176.

[46] VAISHAR, A., KIRCHNER, K., LACINA, J. (2004): Landscape of Small Moravian Towns. In: Kirchner, K., Wojtanowicz, J. (eds.): Cultural Landscapes (pp.57-74). Brno: Regiograph.

[47] VAISHAR, A., KALLABOVÁ, E., ZAPLETALOVÁ, J. (2002): Bystřice nad Pernštejnem a útlum těžby uranu. Urbanismus a územní rozvoj 4(3), 8-16.

[48] VAISHAR, A., ZAPLETALOVÁ, J. (1998): Jemnice: the Role of a Small Town in the Present Stage of Transformation. Moravian Geographical Reports 6(1), 32-42.

[49] ZSILINCSAR, W. (2003): Future Perspectives for Small Urban Centres in Austria. Geografický časopis 55(4), 309-324.

[50] ZUZAŃSKA-ŹYSKO, E. (2003): Population Types of Small Towns in Silesian Province. Bulletin of Geography 2, 139-149.

[51] ZUZAŃSKA-ŹYSKO, E. (2007): Small towns in Śląskie voivodship. Bulletin of Geography 7, 5-14.

[52] ŽıGRAI, F. (2000): Niekol'ko poznámok k problematike malých miest. In: Matlovič, R. (ed.): Urbánny vývoj na rozhraní milénií (pp. 180-182). Prešov: Filozofická fakulta Prešovskej univerzity, Inštitút turizmu a hotelového manažmentu. 